\title{
Isolation and Characterization of Lactic Acid Bacteria Producing Bacteriocin like Inhibitory Substance (BLIS) from “Gappal”, a Dairy Product from Burkina Faso
}

\author{
Abel Tankoano ${ }^{1,2}$, Michel Bakar Diop33, Hagrétou Sawadogo-Lingani², Malick Mbengue ${ }^{4}$, \\ Donatien Kaboré2 ${ }^{2}$ Yves Traoré ${ }^{1}$, Aly Savadogo ${ }^{1^{*}}$ \\ ${ }^{1}$ Laboratoire de Biochimie et Immunologie Appliquée (LaBIA), Université Ouaga I Professeur Joseph Ki-Zerbo, UFR/SVT, \\ Ouagadougou, Burkina Faso \\ ${ }^{2}$ Département Technologie Alimentaire, Centre National de la Recherche Scientifique et Technologique, IRSAT, Ouagadougou, \\ Burkina Faso \\ ${ }^{3}$ Section de Technologies Agroalimentaires (T2A), Université Gaston Berger, UFR S2ATA, Saint-Louis, Sénégal \\ ${ }^{4}$ Laboratoire de Microbiologie Appliquée et Génie Industriel, Université Cheikh Anta Diop, Ecole Supérieure Polytechnique, \\ Dakar-Fann, Sénégal \\ Email: *alysavadogo@gmail.com
}

How to cite this paper: Tankoano, A., Diop, M.B., Sawadogo-Lingani, H., Mbengue, M., Kaboré, D., Traoré, Y. and Savadogo, A. (2019) Isolation and Characterization of Lactic Acid Bacteria Producing Bacteriocin like Inhibitory Substance (BLIS) from "Gappal", a Dairy Product from Burkina Faso. Advances in Microbiology, 9, 343-358.

https://doi.org/10.4236/aim.2019.94020

Received: February 20, 2019

Accepted: April 8, 2019

Published: April 11, 2019

Copyright $\odot 2019$ by author(s) and Scientific Research Publishing Inc. This work is licensed under the Creative Commons Attribution International License (CC BY 4.0).

http://creativecommons.org/licenses/by/4.0/

c) (i) Open Access

\begin{abstract}
Indigenous fermented foods are known for their nutritional and functional properties but they are often spoiled by pathogenic bacteria that can constitute a food safety problem. "Gappal" is a no-thermal treat food based on millet dough and milk and its production conditions can constitute a food safety problem. The aim of this study was to screen and identify LAB producing Bacteriocin-like inhibitory substances using a matrix similar to "Gappal". The detection of potential BLIS was first performed using overlaid method after enrichment of samples in whey and millet dough. The isolates demonstrating inhibiting area were preselected, purified and tested for the presence of antibacterial properties using their neutralized cell-free culture supernatant and subsequently treated with catalase in combination with protease, pepsin or trypsin. The antimicrobial effect of two isolates (Gbf48 and Gbf50) after growth on MRS broth over $12 \mathrm{~h}$ at $30^{\circ} \mathrm{C}$ were active against $E$. faecalis ATCC 19433, M. luteus ATCC 49732, S. aureus ATCC 2523, L. monocytogenes, B. megaterium, B. sphaericus and B. cereus with an activity of $2560 \mathrm{AU} / \mathrm{mL}$. The 16S RNA gene sequencing identification indicated that these isolates are $P e$ diococcus acidilactici. Gbf 48 and Gbf 50 could be used to improve preservative factors for a controlled fermentation of non thermal treatment fermented food for their potential of acidification adds to BLIS production.
\end{abstract}




\section{Keywords}

Bacteriocin, Lactic Acid Bacteria, Pediococcus acidilactici, "Gappal”, Burkina Faso

\section{Introduction}

In developing countries, many indigenous foods are produced by fermentation, using cereals and other raw materials. Fermented cereal porridges and doughs are particularly popular [1] and natural fermentations are considered as useful to improve the nutritional and safety quality of foods and also to extend preservatives properties [2] [3].

Indigenous fermented foods mainly cereal and milk based products are generally contaminated by various microorganisms such as enterobacteria, Listeria monocytogenes and Staphylococcus aureus, responsible of food-borne diseases and also by spore forming bacteria, such as Bacillus cereus [4] [5]. The microbiological quality of fermented cereal based foods is a great importance, as they are often used as basic food for children and the elderly. Many foods based on cereal and milk like "Gappal" are consumed in Burkina Faso [6].

The "Gappal" is a traditional Burkinabe's food obtained by mixture of milk and millet dough. The production of this fermented food is still performed using traditional methods associated with poor hygienic conditions. It results inconsistent quality presentation and short shelf-life, particularly for liquid "Gappal" [6]. The use of starter cultures is still at very early development stages [7] [8] [9] and the use of selected LAB strains as starters could be a possibility for improving safety, quality and reproducibility of fermented foods. In fact, LAB are generally considered as safe microorganisms and they produce a diversity of metabolites over fermentation of certain food matrix that can contribute to control some undesirable bacteria [10] [11] [12].

Bacteriocin, a member of the narrow-spectrum natural antimicrobial compounds have been described as the microbial weapon of choice based upon their abundance and diversity among those produced by bacteria. They are versatile antimicrobial compounds acting through several mechanisms: interference with cell wall formation, disruption of the cytoplasmic membrane, inhibition of protein synthesis, interference with the replication and transcription of DNA, interference with septum formation [13] [14]. Bacteriocins are used in many domains such as agriculture, veterinary medicine as a therapeutic and food technology as a food preservative agent to control various infectious and food-borne pathogens. They can be active against many pathogen including methicillin-resistant Staphylococcus aureus and vancomycin-resistant enterococci [15] [16]. They are considered like the solution to the appearance of antibiotic resistance and the toxicity associated with currently used antibiotics. Bacteriocins are commonly presented having more advantages than chemicals preservatives for food tech- 
nology due to their physical stability and their no-toxicity. Added to the capacity of some LAB to produce bacteriocins, many studies demonstrated the antagonistic properties of this bacteria group by their other metabolites such as acids, alcohols and diacetyl justifying their widespread application as preservatives agent for food [17].

The use of selected LAB demonstrating antimicrobial activity against the most frequent foodborne pathogenic bacteria and capable to growth in millet and milk mixture matrixes could be an affordable way for improving preservatives factors over the steps of fermentation in the perspective of enhancing the safety of no-thermal treatment fermented foods [18]. The purpose of the present study was to screen and characterize LAB producing bacteriocin-like inhibitory substance from "Gappal”.

\section{Method}

\subsection{Gappal Sampling}

Seventeen samples of commercial dried "GappaP" packaged from different parts of Burkina Faso (Dori, Fada N'Gourma, Djibo and Ouagadougou) were collected in purpose to increase the probability to obtain positives strains producing bacteriocin like inhibitory substance (BLIS). The samples were enriched in order to increase the probability to obtain starters for "Gappal" and other cereal foods fermentation. The enrichment broth was made with millet malt powder supplemented with cheese whey.

\subsection{Millet Malt and Cheese Whey Production}

For millet malt production, $1 \mathrm{~kg}$ of millet grains was disinfected with $100 \mathrm{~mL}$ of bleach $(2 \%, v / v)$ during $10 \mathrm{~min}$. The grains were then cleaned and immerged in 2 litters of bicarbonates solution $(0.1 \%, \mathrm{p} / \mathrm{v})$ during $16 \mathrm{~h}$ for $\mathrm{pH}$ adjustment and yeast and molds destruction. The millet grains were then rolled out and covered with a fine fabric during $24 \mathrm{~h}$ for germination.

For whey production, 1 litter of raw milk were pasteurized at $60^{\circ} \mathrm{C}$ during 30 min, inoculated with lyophilic lactic ferment (CSL, Italy) and incubated at $30^{\circ} \mathrm{C}$ for $90 \mathrm{mn} .100 \mu \mathrm{l}$ of commercial pressure was added and the milk was then incubated to convenience temperature according to ferment used for complete coagulation, then the whey was recuperated and conserved at $-20^{\circ} \mathrm{C}$ for next use.

\subsection{Formulation of Enrichment Medium}

For $1 \mathrm{~kg}$ of millet malt, $500 \mathrm{~mL}$ of cheese whey was added, mixed and heated at $80^{\circ} \mathrm{C}$ maximum up to total evaporation of water. The result millet-whey was dried at $60^{\circ} \mathrm{C}$ using air flux (Biosec, Italy) during $24 \mathrm{~h}$ and then milled using coffee mill (GEEPAS, Dubai). The modified MRS broth was performed for $1 \mathrm{~L}$ with millet malt supplemented with $42.00 \mathrm{~g}$ of cheese whey.; $5.00 \mathrm{~g}$ of sodium acetate; $2.00 \mathrm{~g}$ of ammonium citrate; $0.20 \mathrm{~g}$ of magnesium sulphate; $0.05 \mathrm{~g}$ of 
manganese sulphate; $2.00 \mathrm{~g}$ of di-potassium phosphate; $1 \mathrm{~mL}$ of Tween 80 . For pre-enrichment mMRS was supplemented with $0.50 \mathrm{~g}$ of cycloheximid and 1000 UI of polymixin B in order to inhibit the growth of yeast and mold or negative Gram bacteria.

\subsection{LAB Count and Isolation of Antimicrobial Bacteria Using Overlaid Method}

The antagonistic LAB isolation method is a modified method based on those previously used by [19] and consisted to a pre-enrichment using mMRS broth. Ten (10) grams of each dried "Gappal" sample were added to $90 \mathrm{~mL}$ of modified MRS broth. After $24 \mathrm{~h}$ of incubation at $37^{\circ} \mathrm{C}$, the pre-enriched samples were serially diluted and $100 \mu \mathrm{L}$ of suitables dilutions was spread on modified MRS agar plates (mMRS with $0.1 \%$ glucose, and $50 \mu \mathrm{g} / \mathrm{ml}$ of cycloheximide). The plates were incubated for $48 \mathrm{~h}$ at $37^{\circ} \mathrm{C}$ in anaerobic jar containing anaerocult to minimize the formation of hydrogen peroxide and organic acids. The number of colonies were determinate and the plates providing less than 300 colonies were overlaid with $3 \mathrm{~mL}$ of soft nutrient agar $(0.75 \% \mathrm{w} / \mathrm{v}$ agar) inoculated with $30 \mu \mathrm{L}$ of an overnight culture of the indicator organisms (E. faecalis ATCC 19433, $M$. luteus ATCC 49732, S. aureus ATCC 2523, B. sphaericus (local strain) and B. cereus (local strain)). The plates were incubated for $24 \mathrm{~h}$ at $37^{\circ} \mathrm{C}$ and observed for numbering of colonies demonstrating around clearing area meaning an inhibitory action. The colonies was removed from the agar, inoculated in MRS broth and incubated for $16 \mathrm{~h}$ at $37^{\circ} \mathrm{C}$, then they were purified and tested for their antimicrobial activity using the cell-free culture supernatants.

\subsection{Inhibition of Indicators Bacteria by Agar Diffusion Assays}

Cell-free supernatants from overnight cultures of purified isolates showing positive inhibition area against $E$. faecalis ATCC 19433, M. luteus ATCC 49732, $S$. aureus ATCC 2523 , B. sphaericus or B. cereus were obtained by centrifugation (Heraeus Labofuge 300 ) at $2000 \mathrm{~g}$ for $30 \mathrm{~min}$ filtered with micrometer filter (0.22 $\mu \mathrm{m})$ and tested by the agar-well diffusion assay [19]. To determine the nature of the inhibitory activity, a pre-treatment with catalase $(65 \mathrm{UI} / \mathrm{mL})$ and proteolysis enzymes were performed as describe by Diop et al., 2008. Catalase (65 UI/mL) was added to neutralized cell free supernatant (NCFS) to discard the effect of hydrogen peroxide $\left(\mathrm{H}_{2} \mathrm{O}_{2}\right)$. The NCFS was used for enzymatic tests. $180 \mu \mathrm{L}$ of NCFS were incubated with $20 \mu \mathrm{L}$ of the following enzyme solutions: pepsin P7000 (8 UI/mL) which cleave preferntially hydrophobic and aromatic residues in P1 and P1' postitions such as Phe-Val, Gln-His, Glu-Ala, Ala-Leu, Leu-Tyr, Tyr-Leu, Gly-Phe, Phe-Phe and Phe-Tyr bonds in the $\beta$ chain of insulin, trypsin T8003 (7.5 UI $/ \mathrm{mL}$ ) which cleaves peptides on the C-terminal side of lysine and arginine residues and protease P6911 $(0.09 \mathrm{UI} / \mathrm{mL})$ which prefers to hydrolyze peptide bonds on the carboxyl side of glutamic or aspartic acid. The results solution was incubated at $37^{\circ} \mathrm{C}$ for $90 \mathrm{~min}$ to determine the nature of the inhibitory 
activity substance. 21 indicator strains including negative Gram bacteria and positive Gram bacteria were then used to determine the spectrum of the BLIS strains following the well diffusion assay.

\subsection{Phenotypic and Technological Characterization of Isolates}

For preliminary identification, following phenotypic tests were conducted: cell morphology, Gram reaction, catalase activity with 3\% hydrogen peroxide, resistance to bile $(0.3 \%$ and $0.5 \%)$, growth at different $\mathrm{pH}(2.5,6.2$ and 9.6), growth at different concentration of $\mathrm{NaCl}(4 \%, 6.5 \%, 10 \%$ and $15 \%)$, growth at different temperature $\left(10^{\circ} \mathrm{C}, 30^{\circ} \mathrm{C} ; 37^{\circ} \mathrm{C}\right.$ and $\left.45^{\circ} \mathrm{C}\right)$. Fermentation of different sugars was then determined by API 50 CHL (Biomerieux) according to manufacturer's instructions.

\subsection{Molecular and Phylogenetics Analyses}

\section{DNA extraction}

The total genomic DNA was extracted from 1 colony of overnight cultures grown in MRS agar at $37^{\circ} \mathrm{C}$ using InstaGene Matrix (Biorad, UK) according to the manufacturer's instructions. The extracted DNA was stored at $-20^{\circ} \mathrm{C}$ for ulterior use.

\section{Repetitive sequence based PCR}

Repetitive sequence based PCR was realized using the (GTG) $)_{5}$ primer which indicated it ability to discrimate lactic acid bacteria species. The amplification was carried out in a total volume of $25 \mu \mathrm{L}$ containing $2 \mu \mathrm{L}$ of each extracted DNA, $2.5 \mu \mathrm{L}$ of $10 \times$ PCR buffer (Applied Biosystems), $4 \mu \mathrm{L}$ of dNTP (125 $\left.\mathrm{mmol} \cdot \mathrm{l}^{-1}\right), 2 \mu \mathrm{L}$ of $\mathrm{MgCl}_{2}\left(25 \mathrm{mmol} \cdot \mathrm{l}^{-1}\right), 4 \mu \mathrm{L}$ of primer $\left((\mathrm{GTG})_{5}\right.$, 5'-GTGGTGGTGGTGGTG-3'), $2.5 \mathrm{U}$ of Taq polymerase (Applied Biosystems) and $10.25 \mu \mathrm{L}$ of sterile high purity water. The programme of amplication was: initial denaturation at $94^{\circ} \mathrm{C}$ for 4 min followed by 30 cycles of denaturation at $94^{\circ} \mathrm{C}$ for $30 \mathrm{~s}$, annealing at $45^{\circ} \mathrm{C}$ for $1 \mathrm{~min}$ and elongation at $65^{\circ} \mathrm{C}$ for $8 \mathrm{~min}$. The PCR ended with a final extension at $65^{\circ} \mathrm{C}$ for $16 \mathrm{~min}$ and the amplified product cooled at $4^{\circ} \mathrm{C}$. The DNA fragments were separated in agarose gel $2 \%$. The gel was run in 1 XTBE buffer (Tris, Boric acid and EDTA) for $45 \mathrm{~min}$ at $120 \mathrm{~V}$ and photographed using an UV transilluminator [20].

\section{Sequencing and phylogenetic analyses}

The PCR product was purified using QIAquick PCR Purification kit (Qiagen $\mathrm{GmbH}$, Germany). Sequencing was done to generate 550 bp of nucleotides with the primer pD (5'-GTATTACCGCGGCTGCTG-3') corresponding to the E. coli $16 S$ rRNA gene position 536-518. DNA sequencing reactions were carried out commercially by Source BioScience LifeSciences (Waterford, Republic of Ireland). The sequences obtained were compared to those available on EZbiocloud (https://www.ezbiocloud.net/) which is a database containing only 16S RNA sequences of the reference strains [21] and confirm with GenBank database using Blast program (https://blast.ncbi.nlm.nih.gov/). The evolutionary history was 
inferred using the UPGMA method [22] with 500 replicates test of bootstrap. The evolutionary distances were computed using the Maximum Composite Likelihood method [23] and are in the units of the number of base substitutions per site. Evolutionary analyses were conducted in MEGA X [24].

\subsection{Statistical Analysis}

All the results were analysed using Minitab 18 software. Means, Standard deviation and the least significant difference between the means were determined $(\mathrm{p}<$ 0.05). Pearson's correlations among microbiological and physicochemical values were estimated for all the investigated factors.

\section{Results and Discussion}

\subsection{Enrichment Broth Assay and Detection of BLIS Production}

The mean count of LAB for 17 samples in dried "Gappal" before enrichment in mMRS-whey was $5.0 \times 10^{7} \mathrm{CFU} / \mathrm{g}$. The mean prevalence of LAB after the "Gappal" enrichment increased to $7.8 \times 10^{9} \mathrm{CFU} / \mathrm{g}$. These value are statistically significantly different $(\mathrm{p}=0.01) .58 .82 \%$ of "Gappal" samples used for LAB isolation showed the presence of bacterial strains demonstrating a growth inhibition area without acid and $\mathrm{H}_{2} \mathrm{O}_{2}$ neutralization (Table 1). This inhibition may be due to the effect of acidity, $\mathrm{H}_{2} \mathrm{O}_{2}$, probable bacteriocin or a combination of these. $2.42 \%$ of colonies producing an area on the indicator strains recorded, purified and tested by the well method to confirm the presumption of bacteriocin production. The results of the well diffusion method indicated that $0.23 \%$ of the neutralized cell-free supernatant (NCFS) of the total colonies confirmed the activity when the NCFS was treated with catalase $(65 \mathrm{UI} / \mathrm{mL})$ in order to neutralize the effect of hydrogen peroxide (Table 1 ). This result is similar to those obtained by [19] which indicate that $0.2 \%$ of lactic acid bacteria isolated from Senegalese local seafood produce bacteriocin. The enrichment in millet dough and whey contribute to select LAB that are able to grow in the "Gappal" matrix. The counting before enrichment samples of "Gappal" gives the similar values that the study realized on the commercial "Gappal" from Burkina Faso [6]. The medium based on millet supplemented with cheese whey for a nutrient composition similar to "Gappal" constitution allowed increasing and improving the capacity to detect colonies developing inhibitory action against indicator bacteria. These strains could develop in matrix based on milk and millet such as "Gappal". These results are similar to those obtained in previous studies where only two (02) out to forty (40) strains were producer of bacteriocin [16].

\subsection{Activity of the Inhibitory Substance of the Best Isolates}

Based on the best inhibitory spectrum, two bacteriocin-producing isolates codified as "Gbf48" and "Gbf50" were selected for further study. S. aureus and E. faecalis ATCC 19433 indicators strains were the most sensitive to the primary antagonistic developed by selected LAB isolates using overlaid method (no neu- 
tralize cell free supernatant) whereas $M$. luteus, E. faecalis and B. sphaericus demonstrated the highest detection rate among indicator bacteria by NCFS tests. The NCFS of the two selected isolates was tested against positive Gram and negative Gram indicator bacteria using well diffusion method. Among the twenty one (21) indicator strains tested, six (6) were found to be sensitive to Gbf48 and Gbf50 NCFS (Table 2). The highest inhibition diameter was observed against $B$. sphaericus, B. megaterium, B. cereus, M. luteus LMG 3293 and E. faecalis ATCC 19433. The lower inhibition diameter was found against Listeria monocytogenes and Lactococcus lactis. The totalities of negative Gram bacteria tested were not sensitive to the antibacterial substance. Growth inhibition of the negative Gram bacterial strains occurred when no-NCFS were inoculated in the well (Table 2). The no-neutralized cell free substance of the isolates Gbf48 and Gbf50 were found to produce inhibition area against Bacillus cereus, Staphylococcus aureus and all the negative Gram bacteria tested including Escherichia coli, Klebsiella pneumoniae and Salmonella Typhi which are the most contaminant bacteria of commercial "Gappal" [6].

Table 1. Enrichment broth results.

\begin{tabular}{ccccc}
\hline $\begin{array}{c}\text { Lab count } \\
\text { without } \\
\text { enrichment } \\
(\mathrm{CFU} / \mathrm{g})\end{array}$ & $\begin{array}{c}\text { Lab count } \\
\text { Enrichment in } \\
\text { mMRS-Whey } \\
(\mathrm{CFU} / \mathrm{g})\end{array}$ & $\begin{array}{c}\text { Number of } \\
\text { samples } \\
\text { presenting } \\
\text { inhibition area }\end{array}$ & $\begin{array}{c}\text { Percentage of } \\
\text { colonies presenting } \\
\text { inhibition area with } \\
\text { overlaid method }\end{array}$ & $\begin{array}{c}\text { Percentage of } \\
\text { colonies presenting } \\
\text { inhibition area after } \\
\text { NCFS }\end{array}$ \\
\hline $5.0 \times 10^{7 \mathrm{~b}}$ & $7.8 \times 10^{9 \mathrm{a}}$ & $\begin{array}{c}58.82 \% \\
(10 / 17)\end{array}$ & $\begin{array}{c}2.42 \% \\
(52 / 2148)\end{array}$ & $\begin{array}{c}0.23 \% \\
(5 / 2148)\end{array}$
\end{tabular}

The lettrers $\mathrm{a}$ and $\mathrm{b}$ indicated the significative difference between the lactic acid bacteria count $(\mathrm{p}<0.05)$.

Table 2. Activity spectrum of inhibitory substance produced by selected isolates.

\begin{tabular}{|c|c|c|c|c|c|}
\hline \multirow[b]{2}{*}{ Tested strains } & \multirow[b]{2}{*}{ Origin/Reference } & \multicolumn{2}{|c|}{ Gbf48 } & \multicolumn{2}{|c|}{ Gbf50 } \\
\hline & & $\begin{array}{c}\text { Cell free } \\
\text { supernatant }\end{array}$ & $\begin{array}{l}\text { Neutralized } \\
\text { Cell Free } \\
\text { Supernatant }\end{array}$ & $\begin{array}{c}\text { Cell free } \\
\text { supernatant }\end{array}$ & $\begin{array}{c}\text { Neutralized } \\
\text { Cell Free } \\
\text { Supernatant }\end{array}$ \\
\hline Gbf48 & This study & - & - & - & - \\
\hline Gbf50 & This study & - & - & - & - \\
\hline $\begin{array}{c}\text { Micrococcus luteus } \\
\text { ATCC } 49732\end{array}$ & DTA & $19.00 \pm 1.41$ & $11.50 \pm 0.71$ & $15 \pm 1.41$ & $12.50 \pm 0.71$ \\
\hline $\begin{array}{c}\text { Listeria } \\
\text { monocytogenes }\end{array}$ & ESP & $14.00 \pm 1.41$ & $11.00 \pm 1.41$ & $14.5 \pm 0.71$ & - \\
\hline $\begin{array}{c}\text { Enterococcus faecalis } \\
\text { ATCC } 19433\end{array}$ & DTA & $16.00 \pm 1.41$ & $11.50 \pm 2.12$ & $14 \pm 1.41$ & $10.50 \pm 2.12$ \\
\hline $\begin{array}{c}\text { Lactobacillus } \\
\text { brevis }\end{array}$ & ESP & - & - & - & - \\
\hline $\begin{array}{c}\text { Lactococcus } \\
\text { lactis }\end{array}$ & ESP & $10.50 \pm 0.71$ & $9.50 \pm 2.12$ & $10 \pm 0.00$ & $7.50 \pm 0.71$ \\
\hline $\begin{array}{c}\text { Lactobacillus } \\
\text { plantarum }\end{array}$ & ESP & - & - & - & - \\
\hline
\end{tabular}




\begin{tabular}{|c|c|c|c|c|c|}
\hline Continued & & & & & \\
\hline Bacillus sphaericcus & ESP & $16.50 \pm 2.12$ & $14.50 \pm 2.12$ & $15.5 \pm 0.71$ & $15.50 \pm 2.12$ \\
\hline Bacillus megaterium & ESP & $15.00 \pm 2.83$ & - & - & - \\
\hline Bacillus cereus & DTA & $12.00 \pm 1.41$ & - & $9 \pm 0.00$ & $7.50 \pm 0.71$ \\
\hline Bacillus spizizenii & DTA & $12.50 \pm 0.71$ & - & $12 \pm 1.41$ & - \\
\hline Bacillus subtilis & DTA & $10.00 \pm 0.00$ & - & $11.5 \pm 0.71$ & - \\
\hline $\begin{array}{c}\text { Staphylococcus } \\
\text { aureus ATCC } 2523\end{array}$ & DTA & $9.50 \pm 0.71$ & - & $7.5 \pm 0.71$ & - \\
\hline $\begin{array}{l}\text { Staphylococcus } \\
\text { epidermis }\end{array}$ & DTA & $10.50 \pm 0.71$ & $9.50 \pm 0.71$ & $9 \pm 1.41$ & - \\
\hline Escherichia coli & DTA & $16.00 \pm 0.00$ & - & $13.5 \pm 0.71$ & - \\
\hline Citrobacter freundii & DTA & $16.50 \pm 0.71$ & - & $12.5 \pm 0.71$ & - \\
\hline Salmonella Thyphi & DTA & $15.50 \pm 0.71$ & - & $14.5 \pm 0.71$ & - \\
\hline Enterobacter aerogenes & DTA & $14.50 \pm 0.71$ & - & $13.5 \pm 0.71$ & - \\
\hline $\begin{array}{c}\text { Pseudomonas } \\
\text { aeruginosa ATCC } 9027\end{array}$ & DTA & $14.50 \pm 0.71$ & - & $9.5 \pm 0.71$ & - \\
\hline Salmonella niger & DTA & $13.00 \pm 0.00$ & - & $13.5 \pm 0.71$ & - \\
\hline Shigella flexineri & DTA & $14.00 \pm 1.41$ & - & $13.5 \pm 0.71$ & - \\
\hline Klebsiella pneumoniae & DTA & $13.50 \pm 0.71$ & - & $14.5 \pm 0.71$ & - \\
\hline
\end{tabular}

Neutralized cell-free culture supernatants were treated with catalase; -: no inhibition; DTA: Culture collection of Department of Food Technology/National Center for Technological and Scientific Research (Burkina Faso); ESP: Polytechnic High School/University Cheick Anta DIOP (Senegal).

\subsection{Technological Properties of Gbf48 and Gbf50}

The potential for growth, organic acid and bacteriocin-like substance production on MRS broth by Gbf48 and Gbf50 isolates strains were determined at $30^{\circ} \mathrm{C}$, $37^{\circ} \mathrm{C}$ and $42^{\circ} \mathrm{C}$ using Bacillus sphaericus as indicator strain for bacteriocin test. The initial population of inoculates varied between $10^{6}$ and $10^{7} \mathrm{CFU} / \mathrm{mL}$ at $37^{\circ} \mathrm{C}$. The exponential phase of isolates Gbf 48 and Gbf50 begins at 2 hours of incubation and ends at $8 \mathrm{~h}$, corresponding to the beginning of stationary phase (Figure 1). At the beginning of stationary phase, Gbf48 and Gbf50 counting were respectively $1.1 \times 10^{9}$ and $1.2 \times 10^{9} \mathrm{CFU} / \mathrm{mL}$. The growths and acidification kinetics of Gbf48 and Gbf50 were similar (Figure 1 and Figure 2). The acidification kinetic showed that Gbf48 and Gbf50 were able to acidify MRS broth and drop the $\mathrm{pH}$ 3.9 and $1.6 \%$ of acidity after $24 \mathrm{~h}$ (Figure 2 ).

Bacteriocin-like inhibitory substance production evaluated as $\mathrm{AU} / \mathrm{mL}$ over growth of the isolates was carried out by critical dilution at 2 hours of time intervals. The activity of BLIS obtained with Gbf48, and Gbf50 strains culture in MRS broth at $30^{\circ} \mathrm{C}$ and $37^{\circ} \mathrm{C}$ are high than those obtained at $42^{\circ} \mathrm{C}(\mathrm{p}<0.05)$. The highest activity of BLIS from Gbf48 and Gbf50 were $2560 \mathrm{AU} / \mathrm{mL}$ at $30^{\circ} \mathrm{C}$ and $37^{\circ} \mathrm{C}$ while their high activities at $42^{\circ} \mathrm{C}$ were $1280 \mathrm{AU} / \mathrm{mL}$ (Table 3 and Figure 3 ). The inhibition diameter measure indicated that the values obtained at $30^{\circ} \mathrm{C}$ are best than those obtained at $37^{\circ} \mathrm{C}$ for the two isolates. The inhibition 
diameter increase with high number of bacteria and the high activity of antimicrobial substance. Inhibition effect is improved with strong acidification. This explained the inhition of Gram-negative bacteria. However, this activity remains important despite the neutralization of acidity and the effect of hydrogen peroxide. The sensitivity of the antimicrobial substance produced by Gbf48 and Gbf50 toward pepsin, trypsin T8003 and protease P6911 demonstrated that NCFS of Gbf48 and Gbf50 were inactive after proteolytic enzymes treatments which indicated their proteinaceous nature. The detection of Pediococci could be due to their resistance to natural condition of fermentation and drying conditions prevailing for "Gappal". The secretion of bacteriocin like inhibitory substance began in the growth medium after $4 \mathrm{~h}$ of incubation at $30^{\circ} \mathrm{C}$ and until its maximal level at $12 \mathrm{~h}$ of culture corresponding to the early growth until to the first steps of the stationary phase of growth (Figure 1). This result is similar to those obtained by [19] which found that Lactococcus lactis strains from Senegalese seafood produces nisin between $9 \mathrm{~h}$ to $12 \mathrm{~h}$ of growth.

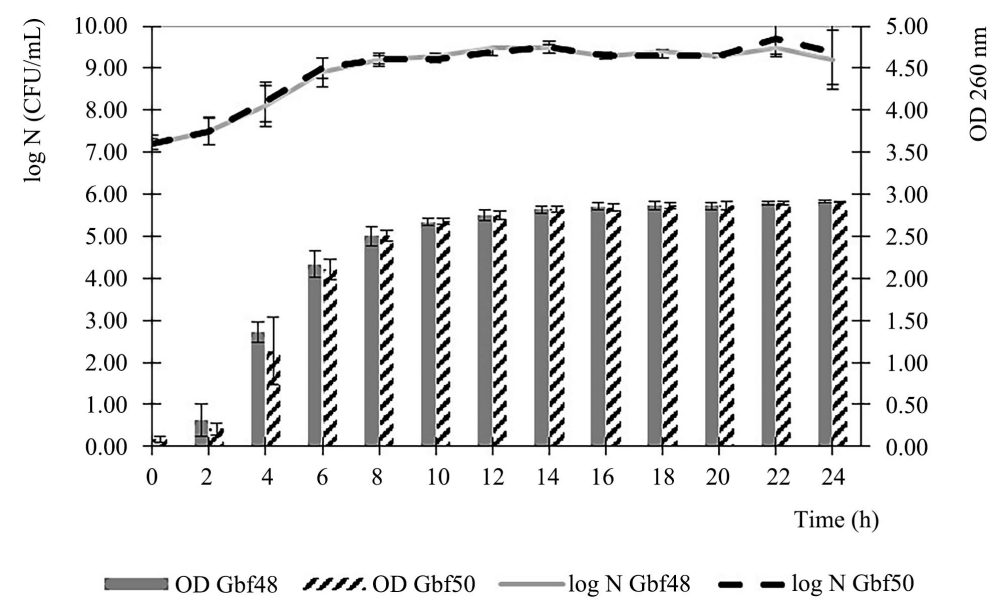

Figure 1. Growth kinetic of selected isolates on MRS broth using optic density and Log CFU/mL methods.

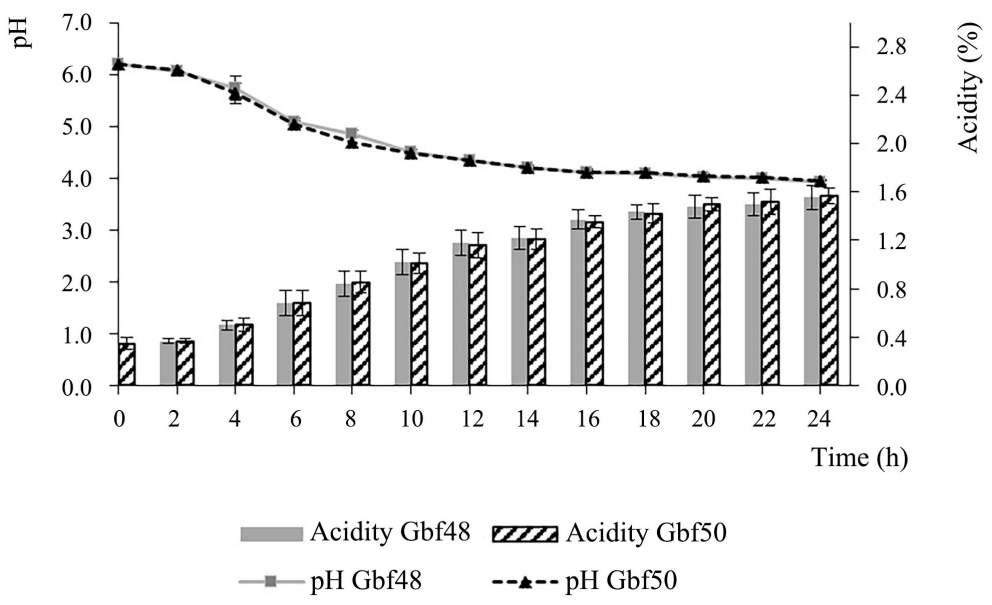

Figure 2. Acidification kinetic of selected bacterial isolates using $\mathrm{pH}$ and acidity determination. 
Table 3. Statistics analysis of growth, acidification and Bacteriocin Like Inhibitory Substance production by selected isolates.

\begin{tabular}{|c|c|c|c|c|c|c|c|c|}
\hline Isolate & $\begin{array}{l}\text { Temp } \\
\left({ }^{\circ} \mathrm{C}\right)\end{array}$ & $\begin{array}{l}\text { Time } \\
(\mathrm{h})\end{array}$ & $\mathrm{pH}$ & $\begin{array}{l}\text { Acidity } \\
(\%)\end{array}$ & $\begin{array}{l}\text { Optic density } \\
600 \mathrm{~nm}\end{array}$ & $\log \mathrm{CFUml}^{-1}$ & $\begin{array}{l}\text { Inibition diameter } \\
\qquad(\mathrm{mm})\end{array}$ & $\begin{array}{c}\text { Activity } \\
\left(\mathrm{AU} \mathrm{mL} \mathrm{mL}^{-1}\right)\end{array}$ \\
\hline & & 0 & $6.20 \pm 0.00$ & $0.34 \pm 0.07$ & $0.07 \pm 0.03$ & $7.23 \pm 0.16$ & $0.00 \pm 0.00$ & $0.00 \pm 0.00$ \\
\hline & & 4 & $5.72 \pm 0.28$ & $0.50 \pm 0.05$ & $1.36 \pm 0.69$ & $7.72 \pm 0.69$ & $9.33 \pm 0.58$ & $20.00 \pm 0.00$ \\
\hline & 30 & 8 & $4.85 \pm 0.10$ & $0.84 \pm 0.15$ & $2.50 \pm 0.16$ & $9.16 \pm 0.11$ & $12.67 \pm 1.15$ & $640.00 \pm 0.00$ \\
\hline & & 12 & $4.35 \pm 0.03$ & $1.18 \pm 0.15$ & $2.75 \pm 0.08$ & $9.48 \pm 0.026$ & $14.00 \pm 1.70$ & $2133.33 \pm 739.01$ \\
\hline & & 16 & $4.12 \pm 0.06$ & $1.37 \pm 0.10$ & $2.85 \pm 0.05$ & $9.32 \pm 0.01$ & $12.33 \pm 0.58$ & $640.00 \pm 0.00$ \\
\hline & & 0 & $6.20 \pm 0.00$ & $0.40 \pm 0.06$ & $0.30 \pm 0.00$ & $7.55 \pm 0.05$ & $0.00 \pm 0.00$ & $0.00 \pm 0.00$ \\
\hline & & 4 & $4.77 \pm 0.09$ & $0.76 \pm 0.02$ & $2.52 \pm 0.13$ & $8.30 \pm 0.06$ & $13.00 \pm 1.41$ & $20.00 \pm 0.00$ \\
\hline \multirow[t]{15}{*}{ Gbf48 } & 37 & 8 & $4.23 \pm \quad 0.07$ & $1.22 \pm 0.03$ & $2.95 \pm 0.24$ & $9.11 \pm 0.13$ & $14.00 \pm 0.00$ & $640.00 \pm 0.00$ \\
\hline & & 12 & $4.08 \pm 0.14$ & $1.31 \pm 0.04$ & $3.16 \pm 0.48$ & $9.21 \pm 0.13$ & $16.00 \pm 2.83$ & $2560.00 \pm 0.00$ \\
\hline & & 16 & $4.05 \pm 0.04$ & $1.46 \pm 0.00$ & $3.32 \pm 0.64$ & $9.40 \pm 0.23$ & $13.5 \pm 0.71$ & $640.00 \pm 0.00$ \\
\hline & & 0 & $6.20 \pm 0.00$ & $0.40 \pm 0.06$ & $0.29 \pm 0.01$ & $7.69 \pm 0.04$ & $0.00 \pm 0.00$ & $0.00 \pm 0.00$ \\
\hline & & 4 & $4.43 \pm 0.06$ & $0.97 \pm 0.01$ & $2.77 \pm 0.18$ & $8.69 \pm 0.49$ & $6.00 \pm 8.49$ & $20.00 \pm 0.00$ \\
\hline & 42 & 8 & $4.07 \pm 0.08$ & $1.39 \pm 0.01$ & $3.14 \pm 0.38$ & $9.26 \pm 0.04$ & $7.00 \pm 9.90$ & $1280.00 \pm 0.00$ \\
\hline & & 12 & $4.06 \pm 0.03$ & $1.41 \pm 0.07$ & $3.25 \pm 0.52$ & $9.35 \pm 0.16$ & $13.00 \pm 1.41$ & $1280.00 \pm 0.00$ \\
\hline & & 16 & $4.03 \pm 0.11$ & $1.43 \pm 0.07$ & $3.20 \pm 0.43$ & $9.3 \pm 0.44$ & $12.00 \pm 0.00$ & $640 \pm 0.00$ \\
\hline & & 0 & $6.20 \pm 0.00$ & $0.34 \pm 0.06$ & $0.08 \pm 0.05$ & $7.20 \pm 0.28$ & $0.00 \pm 0.00$ & $0.00 \pm 0.00$ \\
\hline & & 4 & $5.64 \pm 0.26$ & $0.50 \pm 0.07$ & $0.80 \pm 0.51$ & $8.20 \pm 0.62$ & $9.33 \pm 0.58$ & $20.00 \pm 0.00$ \\
\hline & 30 & 8 & $4.69 \pm 0.12$ & $0.85 \pm 0.12$ & $2.51 \pm 0.08$ & $9.23 \pm 0.17$ & $12.70 \pm 1.15$ & $640.00 \pm 0.00$ \\
\hline & & 12 & $4.34 \pm 0.07$ & $1.16 \pm 0.14$ & $2.75 \pm 0.07$ & $9.39 \pm 0.17$ & $14.00 \pm 3.46$ & $2560.00 \pm 0.00$ \\
\hline & & 16 & $4.12 \pm 0.07$ & $1.35 \pm 0.07$ & $2.84 \pm 0.05$ & $9.33 \pm 0.07$ & $14.00 \pm 1.73$ & $640.00 \pm 0.00$ \\
\hline & & 0 & $6.20 \pm 0.00$ & $0.40 \pm 0.06$ & $0.29 \pm 0.02$ & $7.34 \pm 0.64$ & $0.00 \pm 0.00$ & $0.00 \pm 0.00$ \\
\hline & & 4 & $4.71 \pm 0.16$ & $0.76 \pm 0.06$ & $2.62 \pm 0.27$ & $8.94 \pm 0.21$ & $12.50 \pm 0.71$ & $20.00 \pm 0.00$ \\
\hline \multirow[t]{8}{*}{ Gbf50 } & 37 & 8 & $4.25 \pm 0.06$ & $1.18 \pm 0.03$ & $2.97 \pm 0.25$ & $9.10 \pm 0.15$ & $13.50 \pm 0.71$ & $640.00 \pm 0.00$ \\
\hline & & 12 & $4.05 \pm 0.08$ & $1.34 \pm 0.03$ & $3.19 \pm 0.45$ & $9.31 \pm 0.15$ & $13.00 \pm 1.41$ & $2560.00 \pm 0.00$ \\
\hline & & 16 & $4.03 \pm 0.04$ & $1.43 \pm 0.01$ & $3.32 \pm 0.64$ & $8.89 \pm 0.76$ & $13.00 \pm 1.41$ & $640.00 \pm 0.00$ \\
\hline & & 0 & $6.20 \pm 0.00$ & $0.40 \pm 0.06$ & $0.25 \pm 0.08$ & $7.44 \pm 0.17$ & $0.00 \pm 0.00$ & $0.00 \pm 0.00$ \\
\hline & & 4 & $4.34 \pm 0.18$ & $1.03 \pm 0.04$ & $2.49 \pm 0.21$ & $9.20 \pm 0.12$ & $6.00 \pm 8.49$ & $20.00 \pm 0.00$ \\
\hline & 42 & 8 & $4.17 \pm 0.05$ & $1.32 \pm 0.03$ & $2.65 \pm 0.00$ & $9.30 \pm 0.03$ & $6.50 \pm 9.19$ & $320.00 \pm 0.00$ \\
\hline & & 12 & $4.12 \pm 0.13$ & $1.40 \pm 0.08$ & $2.88 \pm 0.01$ & $9.37 \pm 0.07$ & $13.00 \pm 1.41$ & $1280.00 \pm 0.00$ \\
\hline & & 16 & $4.06 \pm 0.05$ & $1.40 \pm 0.11$ & $2.92 \pm 0.04$ & $9.17 \pm 0.18$ & $13.00 \pm 1.41$ & $1280.00 \pm 0.00$ \\
\hline
\end{tabular}


BLIS of the isolates Gbf48 and Gbf50 could be a Pediocin which is the main bacteriocin produced by Pediococcus acidilactici [13] [14]. According to [14], strains of the food pathogen Bacillus cereus can display resistance to pediocin (from $47.8 \mathrm{AU} / \mathrm{mL}$ to $58.8 \mathrm{AU} / \mathrm{mL}$ ).

The antimicrobial activity of isolates Gbf48 and Gbf50 demonstrated in vitro an inhibitory activity of $2560 \mathrm{AU} / \mathrm{mL}$ against $B$. sphaericus corresponding at minimal concentration of $1 / 128$ in the experimental conditions. This activity was drop stabilized at $1280 \mathrm{AU} / \mathrm{mL}$ over $12 \mathrm{~h}$ of incubation at $30^{\circ} \mathrm{C}$ corresponding to a minimal concentration of $1 / 64$. These values are approximate to those obtained in others studies using Lactobacillus murins (2240 AU/mL) strains under optimized culture conditions [15]. This high activity of NCFS could justify their inhibitory action against Bacillus cereus. In fact, many studies involving Pediococcus genus especially on the genetic, molecular, physiological and technological aspects of $P$. acidilactici demonstrated that they are commonly used in industry to ferment foods such as cereals products, meats and sausages using the preservative properties of pediocin. There is an importatnt correlation betwenn the bacteria growth and the inhibition of the BLIS (Table 4). Added to the decrease of $\mathrm{pH}$, the inhibition of pathogenic bacteria such as negative Gram bacteria is also more important. The statistics analyses indicated that the optimal temperature of acidification and growth of Gbf48, and Gbf50 strains is $30^{\circ} \mathrm{C}$ and Gbf48 present the best inhibition than Gbf50 at this

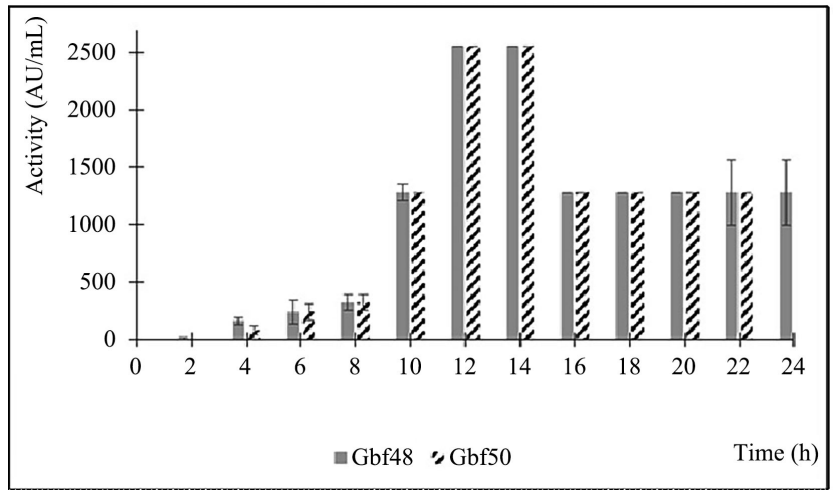

Figure 3. In vitro bacteriocin Like Inhibitory Substance activity by NCFS of selected isolates over growth at $30^{\circ} \mathrm{C}$ on MRS broth evaluated by critical dilution $(\mathrm{AU} / \mathrm{mL})$ in using Bacillus spahericus as indicator using the activity of substance at $30^{\circ} \mathrm{C}$.

Table 4. Correlation betwen inhibition diameters and others parameters.

\begin{tabular}{ccc}
\hline Level & Pearson coefficient & P value \\
\hline Inhibition (mm)-Optic Density & 0.811 & 0.000 \\
Inhibition (mm)-LAB count (Log (CFU/mL)) & 0.743 & 0.000 \\
Inhibition (mm)-Activity (AU/mL) & 0.298 & 0.000 \\
Inhibition (mm)-pH & -0.774 & 0.000 \\
\hline
\end{tabular}


temperature $(\mathrm{p}<0.05)$.

The two isolates are also able to metabolize phytates. Microbial phytases are considered of a great value in upgrading the nutritional quality of plant foods but very few studies have realized with lactic acid bacteria [25]. Contrary to other African cereal and milk based food like dèguè, fura, and arraw, "Gappal" is not thermal treated [26] [27]. The lack of cooking step during the production of "Gappal" conserves the potential nutrients contained in milk and millet dough; a good fermentation process could reduce anti-nutritional factors such as phytates and tannins carried out in millet grains [1] [3]. In fact, the phytate contained in "Gappal" can be reduced by the strains Gbf48, and Gbf50, if used as starter cultures for controlled fermentation. Gbf48 and Gbf50 were cocci which occurred either single or in pairs. They were able to grow in the presence of $0.3 \%$ and $0.5 \%$ of bile, $6.5 \% \mathrm{NaCl}$, at $\mathrm{pH} 9.6$ and $\mathrm{pH} 2$ and at $45^{\circ} \mathrm{C}$ in MRS broth (Table $5)$. These cocci were characterized as homofermentative bacterial strains. They are unable to produce exopolysaccharides. The isolates Gbf48 and Gbf50 are able to acidify MRS broth under $\mathrm{pH} 4$ with an acidity of $1.6 \%$. Similar results were obtained in others studies which demonstrated the associated effect of acidity and bacteriocin from Pediococcus in their environment. In general, the production of bacteriocin may significantly be influence by many factors such as $\mathrm{pH}$, temperature, carbon origin, incubation time and others environmental factors. The results of the present study revealed that isolates Gbf 48 and Gbf50 are able to produce bacteriocin like inhibitory substance under the conditions of "Gappal" production i.e. temperature (ambient temperature approximate to $30^{\circ} \mathrm{C}$ ) and pH (liquid "Gappal" pH 4.31 and dried "Gappal" pH 4.74). The optimum temperature of technological properties and bacteriocin production of the isolates is $30^{\circ} \mathrm{C}$ for Gbf48 and Gbf50 (Table 2).

\subsection{Phenotypical and Molecular Identification of the Isolates}

Based on it activity and it inhibition diameter, the probable best strain for bacteriocin could be Gbf48 for incubation at $30^{\circ} \mathrm{C}$ corresponding to "Gappal" temperature production. API Identification System based on biochemical characteristics (Table 5) indicated that Gbf48 and Gbf50 are related to Pediococcus acidilactici strains at respectively $98.7 \%$ and $96.8 \%$ similarity even they are found from different samples of the same producer. The sequencing concerned only Gbf 48 for it best aptitutes for food stater use. It would be imprudent to conclude on the identity of isolate Gbf50 at this stage of studies. The sequencing of isolate Gbf50 and a molecular identification of the bacteriocin produced will make it possible to conclude whether the two isolates are identical. The molecular identification using sequencing method that confirms that Gbf48 is Pediococcus acidilactici with a similarity of $100 \%$ with the reference strain Pediococcus acidilactici DSM 20284 (T) using Ezbiocloud data base. The phylogenetic tree presented here confirms a narrow genetic relationship between the isolate Gbf48 and some Pediococcus present in NCBI database (Figure 4). 


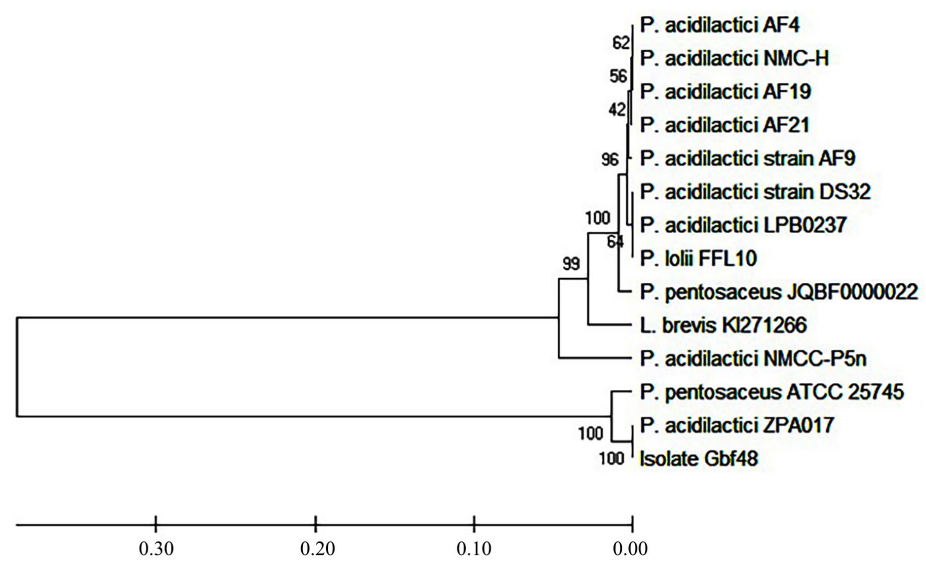

Figure 4. Evolutionary relationships of taxa.

Table 5. Biochemical and technological properties of Gbf48 and Gbf50.

\begin{tabular}{|c|c|c|c|c|c|c|c|c|c|c|c|c|c|}
\hline & GLY & ÉRY & DARA & LARA & RIB & DXYL & LXYL & $\mathrm{ADO}$ & MDX & GAL & GLU & FRU & MNE \\
\hline Gbf 48 & - & - & - & + & + & + & - & - & - & + & + & + & + \\
\hline Gbf50 & - & - & - & + & + & + & - & - & - & + & + & + & + \\
\hline & SBE & RHA & DUL & INO & MAN & SOR & MDM & MDG & NAG & AMY & $\mathrm{ARB}$ & ESC & SAL \\
\hline Gbf48 & - & - & - & - & - & - & - & - & + & - & - & + & - \\
\hline Gbf50 & - & - & - & - & - & - & - & - & + & - & - & + & - \\
\hline & CEL & MAL & LAC & MEL & SAC & TRE & INU & MLZ & RAF & AMD & GLYG & XLT & GEN \\
\hline Gbf48 & + & - & - & + & - & - & - & - & - & - & - & - & + \\
\hline Gbf50 & + & - & - & + & - & - & - & - & - & - & - & - & + \\
\hline & TUR & LYX & TAG & DFUC & LFUC & DARL & LARL & GNT & $2 \mathrm{KG}$ & $5 \mathrm{KG}$ & & & \\
\hline Gbf48 & - & - & + & - & + & - & - & $+1-$ & - & - & & & \\
\hline Gbf50 & - & - & + & - & + & - & - & $+1-$ & - & - & & & \\
\hline & $\begin{array}{c}\mathrm{pH} \\
2\end{array}$ & $\begin{array}{c}\mathrm{pH} \\
5\end{array}$ & $\begin{array}{l}\mathrm{pH} \\
9.6\end{array}$ & \multicolumn{3}{|c|}{ Fermentation } & \multicolumn{2}{|c|}{ Growth to $45^{\circ} \mathrm{C}$} & EPS & \multicolumn{2}{|c|}{ Phytates } & \multicolumn{2}{|c|}{$\begin{array}{l}\text { Bile } 0.3 \% \\
\text { and } 0.5 \%\end{array}$} \\
\hline Gbf48 & + & + & + & \multicolumn{3}{|c|}{ Homofermentative } & + & & - & \multicolumn{2}{|c|}{+} & \multicolumn{2}{|c|}{+} \\
\hline Gbf50 & + & + & + & \multicolumn{3}{|c|}{ Homofermentative } & + & & - & \multicolumn{2}{|c|}{+} & \multicolumn{2}{|c|}{+} \\
\hline
\end{tabular}

+: fermentation of sugar or growth; -: no fermentation of sugar or no growth.

\section{Conclusion}

The present study selected two LABs identified as Pediococcus acidilactici producing bacteriocin like inhibitory substance. The high activity of these BLIS combine to acidity and $\mathrm{H}_{2} \mathrm{O}_{2}$ effect could increase the preservative and sanitary quality of fermented food. The phytase activity associated to accelerate growth of these strains is useful to reduce anti-nutritional factor in cereals and other fermented food containing phytates. Isolates Gbf48 and Gbf50 had a same tech- 
nological characteristic. They are interesting as ferments Lactic Acid Bacteria starter at $30^{\circ} \mathrm{C}$ or $37^{\circ} \mathrm{C}$. Furthermore, it is necessary to study other parameters such as toxicity and experiment fermentation test on this starter culture to improve preservatives properties of "Gappal" production.

\section{Fund}

This work was supported by intra ACP mobility grant of HAAGRIM project (Harmonisation et Amélioration des Programmes de Master et de Doctorat en Agribusiness par la Mobilité entre l'Afrique de l'Ouest, de l'Est et du Centre pour un Développement Socioéconomique Durable).

\section{Conflicts of Interest}

The authors declare no conflicts of interest regarding the publication of this paper.

\section{References}

[1] Blandino, A., Al-Aseeri, M., Pandiella, S., Cantero, D. and Webb, C. (2003) Cereal-Based Fermented Foods and Beverages. Food Research International, 36, 527-543. https://doi.org/10.1016/S0963-9969(03)00009-7

[2] Sawadogo-Lingani, H., Diawara, B., Glover, R., Tano-Debrah, K., Traoré, A. and Jakobsen, M. (2010) Predominant Lactic Acid Bacteria Associated with the Traditional Malting of Sorghum Grains. African Journal of Microbiology Research, 4, 169-179.

http://www.academicjournals.org/journal/AJMR/article-abstract/373F04F11610

[3] Songré-Ouattara, L.T., Mouquet-Rivier, C., Humblot, C., Rochette, I., Diawara, B., and Guyot, J.P. (2010) Ability of Selected Lactic Acid Bacteria to Ferment a Pearl Millet-Soybean Slurry to Produce Gruels for Complementary Foods for Young Children. Journal of Food Science, 75, M261-M269. https://doi.org/10.1111/j.1750-3841.2010.01640.x

[4] Tchekessi, C.K., Bokossa, A., Agbangla, C., Azokpota, P., Daube, G., Scippo, M.L., Korsak, N., Angelov, A. and Bokossa, Y.I. (2014) Production and Microbiological Evaluation of Three Types of "Dèguè", a Local Fermented Drink Made from Milk in Benin. International Journal of Multidisciplinary and Current Research, 2, 714-720. http://hdl.handle.net/2268/174196

[5] Tankoano, A., Kabore, D., Savadogo, A., Soma, A., Fanou-Fogny, N., CompaoreSereme, D., Hounhouigan, J. and Sawadogo-Lingani, H. (2016) Evaluation of Microbiological Quality of Raw Milk, Sour Milk and Artisanal Yoghurt from Ouagadougou, Burkina Faso. African Journal of Microbiology Research, 10, 535-541. https://doi.org/10.5897/AJMR2015.7949

[6] Tankoano, A., Sawadogo-Lingani, H., Savadogo, A., Kaboré, D. and Traoré, Y. (2017) Study of the Process and Microbiological Quality of Gappal, a Fermented food from Burkina Faso Based on Milk and Millet Dough. International Journal of Multidisciplinary and Current Research, 5, 104-110.

http://ijmcr.com/study-of-the-process-and-microbiological-quality-of-gappal-a-fer mented-food-from-burkina-faso-based-on-milk-and-millet-dough/

[7] Tamime, A.Y. and McNulty, D. (1999) Kishk-A Dried Fermented Milk/Cereal Mixture. 4. Microbiological Quality. Dairy Science and Technology, 79, 449-456. 
[8] Nwachukwu, E., Achi, O.K. and Ijeoma, I.O. (2010) Lactic Acid Bacteria in Fermentation of Cereals for the Production of Indigenous Nigerian Foods. African Journal of Food Science and Technology, 1, 21-26.

https://www.interesjournals.org/abstract/lactic-acid-bacteria-in-fermentation-of-cer eals-for-thernproduction-of-indigenous-nigerian-foods-44.html

[9] Sawadogo-Lingani, H., Diawara, B.D., Traoré, A.S. and Jakobsen, M. (2008) Technological Properties of Lactobacillus fermentum Involved in the Processing of Dolo and Pito, West African Sorghum Beers, for the Selection of Starter Cultures. Journal of Applied Microbiology, 104, 873-883. https://doi.org/10.1111/j.1365-2672.2007.03638.x

[10] Kalui, C.M., Mathara, J.M. and Kutima, P.M. (2010) Probiotic Potential of Spontaneously Fermented Cereal Based Foods-A Review. African Journal of Biotechnology, 9, 2490-2498. https://www.ajol.info/index.php/ajb/article/view/79704

[11] Savadogo, A., Tapi A., Chollet M., Wathelet, B., Traoré, A. and Jacques, P. (2011) Identification of Surfactin Producing Strains in Soumbala and Bikalga Fermented Condiments Using Polymerase Chain Reaction and Matrix Assisted Laser Desorption/Ionization-Mass Spectrometry Methods. International Journal of Food Microbiology, 151, 299-306. https://doi.org/10.1016/j.ijfoodmicro.2011.09.022

[12] Mashak, Z., Sodagari, H., Mashak, B. and Niknafs, S. (2014) Chemical and Microbial Properties of Two Iranian Traditional Fermented Cereal-Dairy Based Foods: Kashk-e Zard and Tarkhineh. International Journal of Biosciences, 4, 124-133.

[13] Ahmad, V., Khan, M.S., Jamal, Q.M.S., Alzohairy, M.A., Al Karaawi, M.A. and Siddiqui, M.U. (2017) Antimicrobial Potential of Bacteriocins: In Therapy, Agriculture and Food Preservation. International Journal of Antimicrobial Agents, 49, 1-11. https://doi.org/10.1016/j.ijantimicag.2016.08.016

[14] Porto, M.C.W., Kuniyoshi, T.M., Azevedo, P.O.S., Vitolo, M. and Oliveira, R.P.S. (2017) Pediococcus Spp.: An Important Genus of Lactic Acid Bacteria and Pediocin Producers. Biotechnology Advances, 35, 361-374. https://doi.org/10.1016/j.biotechadv.2017.03.004

[15] Elayaraja, S., Annamalai, N., Mayavu, P. and Balasubramanian, T. (2014) Production, Purification and Characterization of Bacteriocin from Lactobacillus murinus AUo6 and Its Broad Antibacterial Spectrum. Asian Pacific Journal of Tropical Biomedicine, 4, S305-S311. https://doi.org/10.12980/APJTB.4.2014C537

[16] Elyas, Y.Y., Yousif, N.M. and Ahmed, I.A.M. (2015) Screening of Lactic Acid Bacteria from Sudanese Fermented Foods for Bacteriocin Production. Journal of Microbiology, Biotechnology and Food Sciences, 4, 373-378.

[17] Schillinger, U. and Lücke, F.K. (1989) Antibacterial Activity of Lactobacillus Sake Isolated from Meat. Applied and Environmental Microbiology, 55, 1901-1906. http://aem.asm.org/content/55/8/1901

[18] Valenzuela, A.S., Ruiz, G.D., Omar, N.B., Abriouel, H., López, R.L., Cañamero M.M., Ortega, E. and Gálvez, A. (2008) Inhibition of Food Poisoning and Pathogenic Bacteria by Lactobacillus plantarum Strain 2.9 Isolated from Ben Saalga, Both in a Culture Medium and in Food. Food Control, 19, 842-848. https://doi.org/10.1016/j.foodcont.2007.08.009

[19] Diop, M., Dortu, C., Destain, J., Tine, E. and Thonart, P. (2008) In Vitro Detection and Characterization of Bacteriocin-Like Inhibitory Activity of Lactic Acid Bacteria (LAB) Isolated from Senegalese Local Food Products. African Journal of Microbiology Research, 2, 206-216. http://hdl.handle.net/2268/5558

[20] Ouoba, L.I.I., Nyanga-Koumou, C.A.G., Parkouda, C., Sawadogo, H., Kobawila, 
S.C., Keleke, S. and Sutherland, J.P. (2010) Genotypic Diversity of Lactic Acid Bacteria Isolated from African Traditional Alkaline-Fermented Foods. Journal of Applied Microbiology, 108, 2019-2029.

[21] Yoon, S.H., Ha, S.M., Kwon, S., Lim, J., Kim, Y., Seo, H. and Chun, J. (2017) Introducing EzBioCloud: A Taxonomically United Database of 16S rRNA Gene Sequences and Whole-Genome Assemblies. International Journal of Systematic and Evolutionary Microbiology, 67, 1613-1617. https://doi.org/10.1099/ijsem.0.001755

[22] Sneath, P.H.A. and Sokal, R.R. (1973) The Principles and Practice of Numerical Classification. Taxon, 12, 190-199.

[23] Tamura, K., Nei, M. and Kumar, S. (2004) Prospects for Inferring Very Large Phylogenies by Using the Neighbor-Joining Method. Proceedings of the National Academy of Sciences of the United States of America, 101, 11030-11035 https://doi.org/10.1073/pnas.0404206101

[24] Kumar, S., Nei, M., Dudley, J. and Tamura, K. (2008) MEGA: A Biologist-Centric Software for Evolutionary Analysis of DNA and Protein Sequences. Brief in Bioinformatics, 9, 299-306. https://doi.org/10.1093/bib/bbn017

[25] Aziz, G., Nawaz, M., Anjum, A., Yaqub, T., Nazir, J., Khan, S. and Aziz, K. (2015) Isolation and Characterization of Phytase Producing Bacterial Isolates from Soil. Journal of Animal and Plant Sciences, 25, 771-776. http://www.thejaps.org.pk/Volume/2015/25-03/index.php

[26] Hama, F., Savadogo, A., Ouattara, C.A.T. and Traore, A.S. (2009) Biochemical, Microbial and Processing Study of Dèguè a Fermented Food (From Pearl millet dough) from Burkina Faso. Pakistan Journal of Nutrition, 8, 759-764. https://doi.org/10.3923/pjn.2009.759.764

[27] Owusu-Kwarteng, J., Akabanda, F., Nielsen, D.S., Tano-Debrah, K., Glover, R.L.K. and Jespersen, L. (2012) Identification of Lactic Acid Bacteria Isolated during Traditional Fura Processing in Ghana. Food Microbiology, 32, 72-78.

https://doi.org/10.1016/j.fm.2012.04.010 